\title{
SISTEM INFORMASI PELAYANAN KARIER SISWA DAN ALUMNI BERBASIS FRAMEWORK CODEIGNITER
}

\author{
Wildan Yasa Kuswandi ${ }^{1)}$, Nurul Ichsan ${ }^{2)}$, Erni Ermawati ${ }^{3)}$, Tri Wahyuni ${ }^{4)}$ \\ wildanvirtual@gmail.com ${ }^{1)}$, nurul.nrc@bsi.ac.id ${ }^{2)}$,erni.ert@bsi.ac.id ${ }^{3)}$, tri.twy@bsi.ac.id ${ }^{4)}$
}

\begin{abstract}
Abstrak
Pelayanan karier siswa dan alumni yang masih dilakukan dengan cara konvensional dirasa kurang efektif dan memiliki kendala baik dari segi teknis maupun proses penyampaian lamarannya, sehingga para pencari kerja terlambat untuk merebut peluang pekerjaan. SMK Negeri 1 Kota Tasikmalaya membentuk Bursa Kerja Khusus (BKK) yang bertugas melayani jenjang karier siswa dan alumni. Akan tetapi, pelayanan yang diberikan masih pada sebatas penyebaran informasi melalui media sosial dan mading tanpa adanya pemantauan dan bantuan layanan lanjutan. Untuk menyelesaikan permasalahan tersebut, pihak sekolah memerlukan sistem informasi pelayanan karier online untuk menunjang kinerja BKK. Sistem informasi pelayanan karier online ini diharapkan siswa dan alumni dapat terbantu dari segi penyebaran informasi lowongan pekerjaan dan proses penyampaian lamaran. Selain itu juga pihak sekolah dapat memantau perkembangan lulusannya, sehingga dapat menjadi bahan evaluasi lanjutan demi meningkatkan kualitas SMK Negeri 1 Kota Tasikmalaya begitu pula siswa dan alumninya. Sistem informasi pelayanan karier siswa dan alumni berbasis web ini dapat membantu menyebarkan informasi lowongan pekerjaan secara realtime ke akun website dan kontak alumni yang terdaftar dan berkas lamaran dapat langsung terkirim ke akun perusahaan tanpa harus dititipkan melalui pihak lain.
\end{abstract}

Kata Kunci: Sistem Informasi, Pelayanan Karier, Lowongan Pekerjaan

\begin{abstract}
Career service for students and alumnus still doing by conventional felt it's not effective and have many constraint from technical side or applying job process, so job seekers be late to get job. SMK Negeri 1 Kota Tasikmalaya build Bursa Kerja Khusus (BKK) having task to serve students and alumnus's career. But, in shape of service process still limit by share via social media and without monitoring and service helper continuously. To solve the problems, school need an online career services information system to help BKK's tasks. With this online career services information system hope that students and alumnus could solved from share of job information side and applying job process. Else the school can monitoring alumnus's career development so it will be next evaluation for to increase school quality also his students and alumnus. Career services information system for students and alumnus of web based can help sharing information job with realtime to website account and alumnus's registered contact and can direct send to company's account without mediator or put to other people.
\end{abstract}

Keyword : Information System, Career Service, Job Vacancy 


\section{PENDAHULUAN}

Saat ini teknologi informasi berkembang dengan sangat pesat sehingga untuk berkomunikasi dan mendapatkan informasi tidak lagi terbatas oleh jarak dan waktu. Perkembangan teknologi informasi yang terus berlanjut membawa dampak pada proses pengolahan data dan penyampaian informasi sesuai kebutuhan. Sehingga setiap hal dapat dilakukan dengan lebih cepat juga praktis. Hal ini berdampak pada berbagai aspek, salah satunya persaingan merebut peluang pekerjaan menjadi semakin ketat terlebih di era MEA (Masyarajat Ekonomi ASEAN) ini para pencari kerja akan tertinggal jika tidak mampu memanfaatkan kecanggihan teknologi informasi. Dalam mencari informasi lowongan pekerjaan, pelamar biasanya menggunakan cara manual, yaitu pelamar harus mendatangi perusahaan yang dituju dengan membawa berkas persyaratan, surat lamaran dan persyaratan lainnya yang menggunakan banyak kertas serta adanya kemungkinan persyaratan yang dibawa akan mudah sobek atau terkena basah ketika sampai di perusahaan dan jika harus menggunakan jasa pengiriman barang, maka pelamar tentu harus mengeluarkan biaya pengiriman. Cara tersebut dirasa kurang efektif dan seringkali hasil yang didapat tidak sesuai dengan informasi, karena informasi yang didapat bukan dari sumber yang resmi. Bahkan berkas lamaran yang dititipkan di security terkadang tidak sampai ke bagian HRD dan hanya disimpan di ruang security tanpa adanya tindak lanjut.

Menurut Handoko dalam Nugroho dan Nugroho (2012:381), keresahan yang sering dialami oleh siswa terhadap masa depannya memberikan isyarat bagi dunia pendidikan khususnya bagi Sekolah Menengah Umum (SMU) dan Sekolah Menengah Kejuruan (SMK) untuk bertanggung jawab mengemban tugas pengembangan kemampuan siswa dalam merencanakan karirnya, baik melalui kegiatan-kegiatan praktek lapangan (ekstra kurikuler) maupun kegiatan bimbingan karir.

SMK Negeri 1 Kota Tasikmalaya sebagai salah satu sekolah negeri terkemuka di Tasikmalaya yang telah melahirkan ribuan alumni kompetitif dan mampu bersaing dalam dunia kerja. Hal ini merupakan suatu mata rantai yang tidak bisa dipisahkan dari proses pendidikan di SMK Negeri 1 Kota Tasikmalaya. Agar siswa dan alumninya kompetitif dan berdaya saing tinggi, pihak sekolah mendirikan Bursa Kerja Khusus (BKK) dengan tujuan memberikan pelayanan kepada siswa dan alumni dalam meningkatkan mutu dan keahlian diri serta memberikan pembekalan terhadap cara pandang siswa dan alumni dalam menyongsong masa depan. Saat ini proses pelayanan BKK masih sebatas penyebaran informasi saja baik melalui mading maupun melalui media sosial tanpa adanya pemantauan dan penyediaan fasilitas penunjang kebutuhan karir. Untuk menunjang kinerja pelayanan Bursa Kerja Khusus (BKK) tersebut, perlu adanya sistem informasi modern dengan memanfaatkan internet agar mempermudah penyebaran informasi serta pelayanan karier bagi siswa dan alumi.

Menurut Syahputra dan Hati (2015:134), dengan melihat permasalahan yang muncul di Departemen Konseling dan Pengembangan Karier (DKPK) Institut Teknologi Budi Utomo, peneliti mencoba merancang sistem informasi pendaftaran pusat karier secara online untuk mengurangi dan mengatasi permasalahan tersebut. Identifikasi masalah pada penelitian ini adalah mengenai sistem pendaftaran career center masih dilakukan dengan cara konfensional sehingga kurang efektif dan efisien. Peneliti mencoba merancang sistem informasi pendaftaran career center secara online sehingga dapat meningkatkan pelayanan Departemen Konseling dan Pengembangan Karier (DKPK) Institut Teknologi Budi Utomo. Dari pembahasan tersebut maka maka dibutuhkan suatu sistem untuk menunjang pelayanan karier bagi siswa dan alumni SMK Negeri 1 Kota Tasikmalaya.

\section{TINJAUAN PUSTAKA}

\section{Sistem Informasi Penjualan}

Menurut Gordon B Davis dalam buku Sutabri (2012:6), menyatakan bahwa "pengertian sistem adalah sistem bisa berupa abstrak atau fisik. Sistem yang abstrak adalah susunan gagasan-gagasan atau konsepsi yang teratur yang saling bergantung. Sedangkan sistem yang bersifat fisik adalah serangkaian unsur yang bekerja sama untuk mencapai suatu tujuan".

Menurut Gordon B. Davis dalam buku Sutabri (2012:1), menyatakan bahwa "informasi adalah data yang telah diproses ke dalam suatu bentuk yang mempunyai arti bagi si penerima dan mempunyai nilai nyata dan terasa bagi keputusan saat itu atau keputusan mendatang". Pengertian Sistem Informasi menurut Tantra (2012:2), menyatakan bahwa "sistem informasi adalah cara yang terorganisir untuk mengumpulkan, memasukan, dan memproses 
data dan menyimpannya, mengelola, mengontrol dan melaporkannya sehingga dapat mendukung perusahaan atau organisasi untuk mencapai tujuan".

\section{Website}

Menurut Sibero (2011:11), "World Wide Web (www) atau yang dikenal juga dengan istilah web atau website adalah suatu sistem yang berkaitan dengan dokumen, digunakan sebagai media untuk menampilkan teks, gambar, multimedia dan lainnya pada jaringan internet.". Beberapa hal yang berkaitan dengan website diantaranya:

\section{Web Server}

Menurut Sibero (2011:11), “Web server adalah sebuah komputer yang terdiri dari perangkat keras dan perangkat lunak yang bekerja sebagai penyedia layanan yang dapat diakses oleh banyak pengguna, sehingga dibutuhkan kapasitas dan kapabilitas yang besar dibandingkan dengan PC biasa".

2. Web Browser

Menurut Sibero (2011:12), “Web browser adalah aplikasi perangkat lunak yang digunakan untuk mengambil dan menyajikan sumber informasi dari web server".

Contoh web browser : Mozilla Firefox, Google Chrome, Internet Explorer dan lain sebagainya.

3. Internet

Menurut Sibero (2011:10), "Internet (Internconnected Network) adalah jaringan komputer yang menghubungkan antar jaringan secara global, internet dapat juga disebut jaringan dalam suatu jaringan yang luas".

\section{Web Hosting}

Menurut Sujatmiko dan Ariyus (2018:27), "Web Hosting adalah salah satu bentuk layanan jasa penyewaan tempat di internet yang memungkinkan perorangan ataupun organisasi menampilkan layanan jasa atau produknya di web atau situs internet".

\section{Bahasa Pemrograman}

1. HTML

Menurut Sibero (2011:19), "Hyper Text Markup Language atau HTML adalah bahasa yang digunakan pada dokumen web sebagai bahasa untuk pertukaran dokumen web."

\section{CSS}

Menurut Sibero (2011:112), "CSS (Caccading Style Sheet) adalah bahasa yang diguankan untuk mengembangkan dan menata gaya pengaturan halaman web." Sedangkan menurut Hidayat dan Andhika (2016:52), "Cascading Style Sheet (CSS) merupakan aturan untuk mengatur beberapa komponen dalam sebuah web sehingga akan lebih terstruktur dan seragam".

3. PHP

Menurut Fahmi et.al (2016:2), "PHP adalah bahasa pemrograman script. Perbedaannya adalah, jika Java Script secara umum digunakan untuk pemrograman di sisi klien, PHP secara umum digunakan untuk pemrograman di sisi server". Sedangkan menurut Sibero (2011:49), menyatakan bahwa "PHP (PHP Hypertext Preprocessor) adalah pemrograman interpreter, yaitu proses penerjemahan baris kode sumber menjadi kode mesin yang dimengerti komputer secara langsung pada saat baris kode dijalankan".

4. jQuery

Menurut Sibero (2011:218), “jQuery adalah salah satu Javascript Framework yang dbuat untuk meringkas penggunaan CSS Selector dalam suatu pustaka fungsi dengan ciri khas pada penggunaan perintahnya, prefix untuk jQuery dengan tanda $\$$ kemudian dilanjutkan dengan fungsi atau perintah."

\section{Basis Data}

\section{1. $M y S Q L$}

Menurut Sibero (2011:97), "MySQL atau dibaca "My Sekuel" adalah suatu RDBMS (Relational Database Manegement Sistem) yaitu aplikasi sistem yang menjalankan fungsi pengolahan data". Sedangkan menurut Warman dan Zahni (2013:33) "MySQL adalah sebuah system manajemen database. Database adalah sekumpulan data yang terstruktur".

2. PHPMyAdmin

Menurut Sibero (2011:376), "PHP MyAdmin adalah aplikasi web yang digunakan untuk administrasi database MySQL yang mendukung berbagai aktifitas seperti 
pengolahan data, tabel, relasi antar tabel dan lain-lain".

\section{Teori Pendukung}

Teori pendukung disini berisi tentang penjelasan peralatan-peralatan yang digunakan oleh penulis dalam menyusun penelitian ini.

\section{Adobe Dreamweaver}

Menurut Sibero (2013:384), mengemukakan bahwa "Adobe Dreamweaver adalah suatu produk web developer yang dikembangkan oleh Adobe System Inc. Sebelumnya produk Dreamweaver dikembangkan oleh Macromedia Inc, yang kemudian sampai dengan saat ini pengembangannya diteruskan oleh Adobe System".

2. Adobe Photoshop

Menurut Riyanto (2014:13), “Adobe Photoshop adalah perangkat lunak berbasis bitmap untuk kebutuhan editor citra yang diproduksi oleh Adobe System, dikhususkan untuk mengedit foto atau gambar dan penambahan efek khusus".

3. Codeigniter

Dalam Wahana Komputer (2011:2), "Codeigniter merupakan aplikasi open source yang berupa framework dengan model MVC untuk membangun website dinamis menggunakan PHP".

4. Twitter Bootstrap

Menurut Fadul (2014), mengemukakan bahwa "Bootstrap adalah front-end framework yang solek, bagus dan luar biasa yang mengedapankan tampilan untuk mobile device (handphone, smartphone dan lainlain.) guna mempercepat dan mempermudah pengembangan website. Bootstrap juga menyediakan HTML, CSS dan Javascript siap pakai dan mudah untuk dikembangkan.

5. XAMPP

Menurut Nugroho (2014:1), mengemukakan bahwa XAMPP terdiri atas satu paket program web server, diantaranya adalah Apache, PHP dan MySQL. Dimana, Apache adalah web server untuk menjalankan aplikasi web berbasis PHP, PHP adalah kompilator skrip yang dibuat dari teks editor seperti notepad dan dreamweaver, sedangkan mysql adalah database untuk menyimpan data. Dengan menginstal XAMPP, maka secara otomatis komputer atau laptop anda akan menjadi web server.

UML

Menurut Shalahuddin dan Rosa (2014:133), mengemukakan "UML (Unified Model Language) adalah salah satu standar bahasa yang banyak digunakan di dunia industri untuk mendefinisikan requirenment, membuat analisis \& desain, serta menggambarkan arsitektur dalam pemrograman berorientasi objek".

1. Use Case Diagram

Menurut Salahddin dan Rosa (2014:155), Use case atau diagram use case merupakan pemodelan untuk kelakukan (behavior) sistem informasi yang akan dibuat. Use case mendeskripsikan sebuah interaksi antara satu atau lebih aktor dengan dengan sistem informasi yang akan dibuat. Secara kasar, use case digunakan untuk mengetahui fungsi apa saja yang ada di dalam sebuah sistem informasi dan apa saja yang berhak menggunakan fungsi-fungsi itu.

2. Activity Diagram

Menurut Shalahuddin dan Rosa (2014:161), "Diagram aktifitas atau activity diagram menggambarkan workflow (aliran kerja) atau aktivitas dari sebuah sistem atau proses bisnis atau menu yang ada pada perangkat lunak".

3. Class Diagram

Menurut Shalahuddin dan Rosa (2014:141), "Diagram kelas atau class diagram menggambarkan struktur sistem dari segi pendefinisan kelas-kelas yang akan dibuat untuk membangun sistem".

4. Sequence Diagram

Menurut Shalahuddin dan Rosa (2014:165), "Diagram sekuen menggambarkan kelakuan objek pada use case dengan mendeskripsikan waktu hidup objek dan message yang akan dikirimkan dan diterima antar objek".

5. Deployment Diagram

Menurut Shalahuddin dan Rosa (2014:154), "Diagram deployment atau deployment diagram menunjukkan konfigurasi komponen dalam proses eksekusi aplikasi." 


\section{Conceptual Data Model}

Menurut Shalahuddin dan Rosa (2014:59), "CDM (Conceptual Data Model) atau model konsep data merupakan konsep yan berkaitan dengan pandangan pemakai terhadap data yang disimpan dalam basis data."

\section{Physical Data Model}

Menurut Shalahuddin dan Rosa (2014:63), mengemukakan bahwa "Model relasional atau Physical Data Model (PDM) adalah model yang menggunakan sejumlah tabel untuk menggambarkan data serta hubungan antar data."

\section{Penelitian Terkait}

Menurut Hartono dalam Haryani (2013:183), pada era kompetisi yang semakin ketat, setiap organisasi dituntut untuk meningkatkan kinerjanya agar dapat memenangkan persaingan. Kunci utama kinerja adalah bagaimana organisasi mampu mengembangkan Sumber Daya Manusia (SDM). Kegiatan pengembangan sumber daya manusia untuk dapat diandalkan dalam meningkatkan fungsi organisasi bukanlah pekerjaan yang mudah. Peranan Departemen Konseling dan Pengembangan Karier (DKPK) sangatlah penting, dimana dapat membantu dalam melaksanakan pekerjaan yang efektif dan efisien. Dalam proses pendaftaran career center adanya masalah yang timbul dari kegiatan tersebut. Diantaranya adalah pada Departemen Konseling dan Pengembangan Karier (DKPK) belum memiliki aplikasi sistem pendaftaran yang dikelola dengan baik, selain itu pendaftaran masih dilakukan dengan cara konvensional. (Syahputra dan Hati, 2015:133).

\section{METODE PENELITIAN}

Metode yang digunakan pada
pengembangan perangkat lunak ini
menggunakan model waterfall.
Menurut Salahudin dan Rosa (2014:28-
30), mengemukakan bahwa "Model SDLC Air
terjun (waterfall) sering juga disebut model
sekuensial linier (sequential linear) atau alur
hidup klasik (classic lifecycle). Model air terjun

menyediakan pendekatan alur hidup perangkat lunak secara sekuensial atau terurut dimulai dari analisis, desain, pengodean, pengujian, dan tahap pendukung (support)".

\section{A. Analisa Kebutuhan Software}

Pengembangan kasus ini dibutuhkan pengumpulan data berupa profil sekolah, database siswa dan alumni serta daftar perushaan yang telah bekerja sama dengan pihak sekolah. Untuk proses perancangan sistem yang digunakan adalah Personal Computer (PC) yang sudah terpasang software sebagai berikut:

a. Web server seperti: XAMPP/WAMPP dsb.

b. Code editor seperti: Notepad ++, Sublime Text, Adobe Dreamweaver dsb.

c. Image editor seperti: Adobe Photoshop, Corel Draw GIMP, Inkscape dsb.

d. Web browser seperti: Mozila Firefox, Google Chrome, Opera dsb

e. Koneksi internet untuk mencari referensi coding dan fungsi sistem.

\section{B. Desain}

Kasus ini akan dirancang tampilan untuk siswa dan alumni sebagai user untuk mengakses pencarian lowongan pekerjaan, melengkapi berkas dan melamar pekerjaan. Untuk pihak sekolah sebagai admin, dirancang tampilan untuk melihat daftar perushaan, siswa dan alumni yang terdaftar dan melamar pekerjaan serta tampilan untuk menambah lowongan pekerjaan dan informasi-informasi yang berhubungan dengan karier.

\section{Code Generation}

Perancangan sistem informasi ini menggunakan pemrograman berorientasi objek. Bahasa pemrograman yang digunakan diantaranya PHP, CSS, HTML, JQuery dan MySQL

D. Testing

Tahap ini dilakukan setelah kode program selesai dan program dapat dijalankan. Pengujian dilakukan pada logika internal dari perangkat lunak, fungsi dan mencari segala kemungkinan kesalahan. Pada tahap ini dilakukan juga pemeriksaan apakah program telah sesuai dengan hasil yang diinginkan atau tidak.

\section{E. Support}

Tahap ini pemeliharaan perangkat lunak diperlukan agar sistem dapat berfungsi secara 
optimal dan terus menerus, demikian pula pemeliharaan dilakukan ketika ada penambahan fungsi yang diperlukan.

\section{HASIL DAN PEMBAHASAN}

\section{Identifikasi Kebutuhan}

Sistem Informasi Pelayanan Karier Bagi Siswa dan Alumni SMK Negeri 1 Kota Tasikmalaya Berbasis Web adalah sistem yang membantu menghubungkan antara pencari kerja (siswa dan alumni) dan perusahaan (telah bekerja sama dengan pihak sekolah) yang membutuhkan tenaga pekerja melalui lembaga BKK (Bursa Kerja Khusus). Sistem ini mempunyai 3 jenis hak akses yaitu admin sebagai pihak BKK, member sebagai pihak pencari kerja (siswa/alumni) dan perusahaan sebagai pihak penyedia lowongan pekerjaan yang telah bekerja sama dengan sekolah.

\section{Use Case Diagram}

a. Use Case Diagram Kegiatan Member

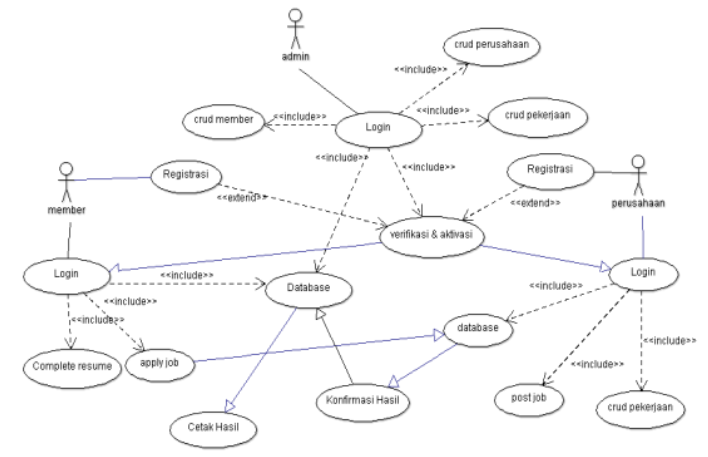

Gambar 1. Use Case Diagram Alur Sistem Usulan

\section{Activity Diagram}

Activity diagram menggambarkan berbagai alir aktivitas dalam sistem yang sedang dirancang, bagaimana masing-masing alir berawal, decision yang mungkin terjadi, dan bagaimana mereka berakhir.

a. Activity Diagram Proses Pelamaran Kerja Secara Umum

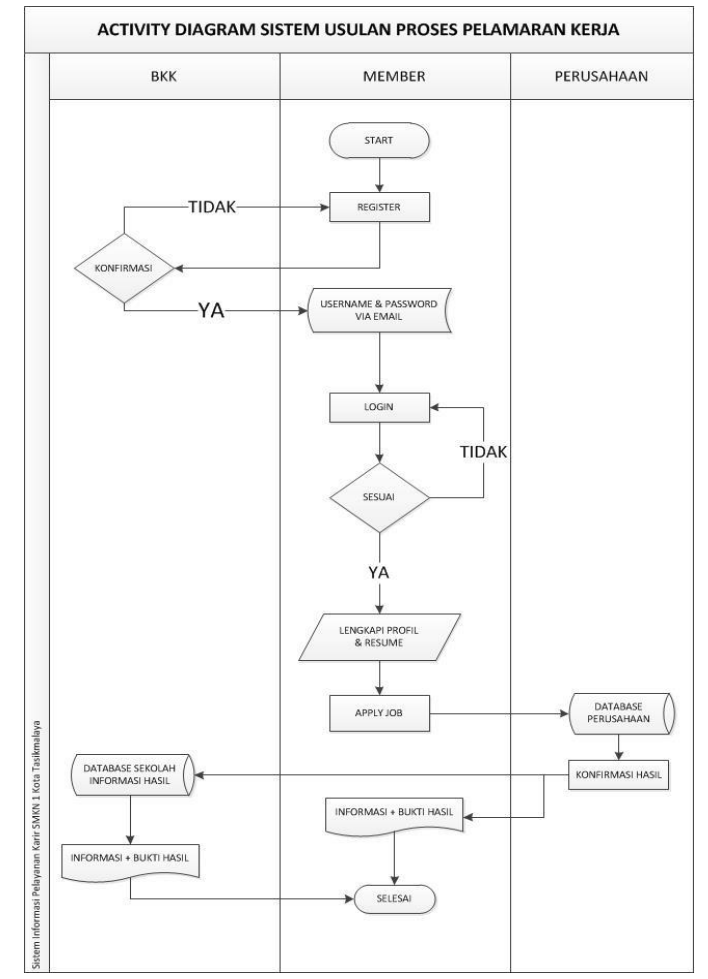

Gambar 2. Activity Diagram Proses Pelamaran Kerja Secara Umum

\section{Logical Data Model}

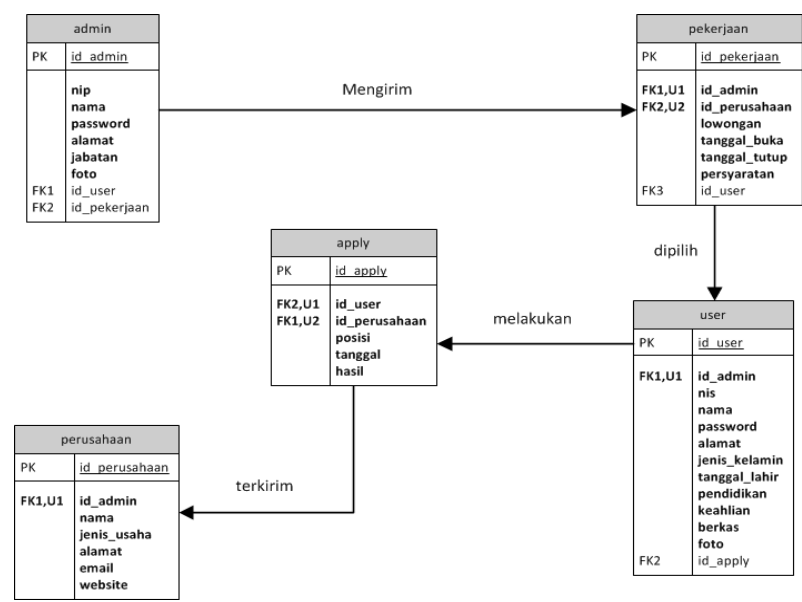

Gambar 3. Entity Relationship Diagram 


\section{Physichal Data Model}



Gambar 4. Logical Record Structure

\section{Class Diagram}

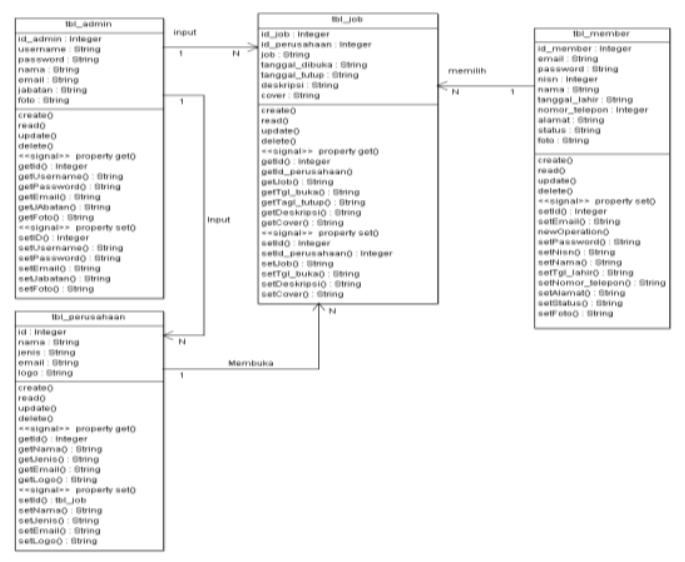

Gambar 4. Class Diagram

\section{Tampilan Antar Muka}

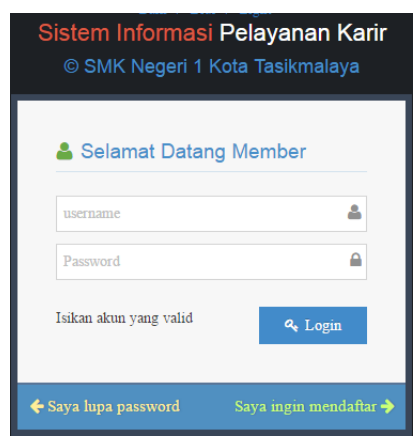

Gambar 5. Tampilan login

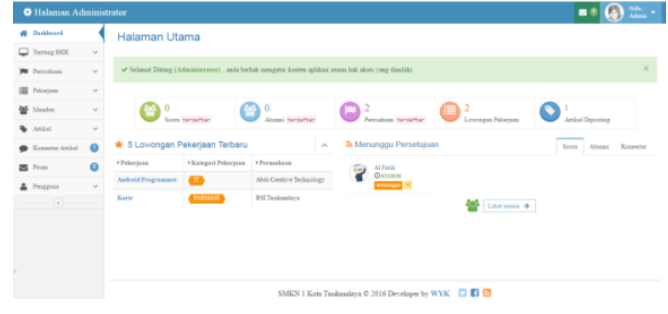

Gambar 6. Tampilan Dashboard admin

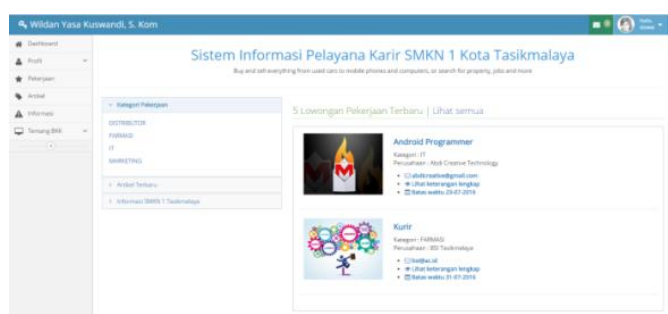

Gambar 7. Tampilan Dashboard Member

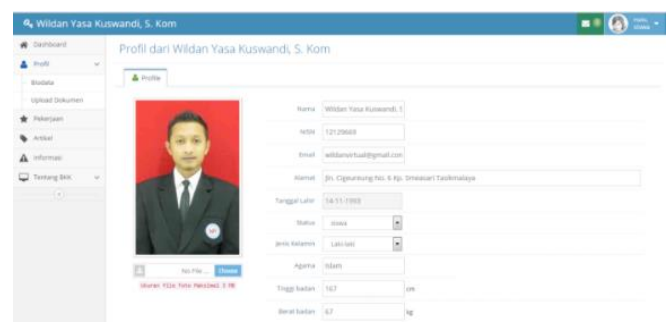

Gambar 8. Tampilan halaman profil pelamar

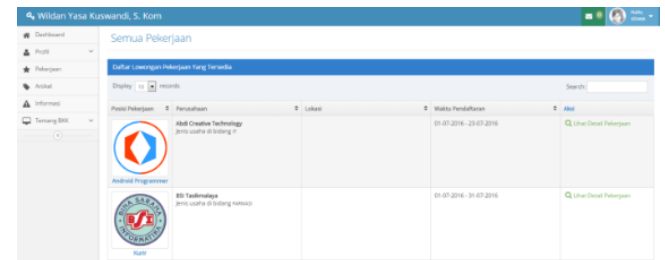

Gambar 9. Tampilan halaman daftar pekerjaan

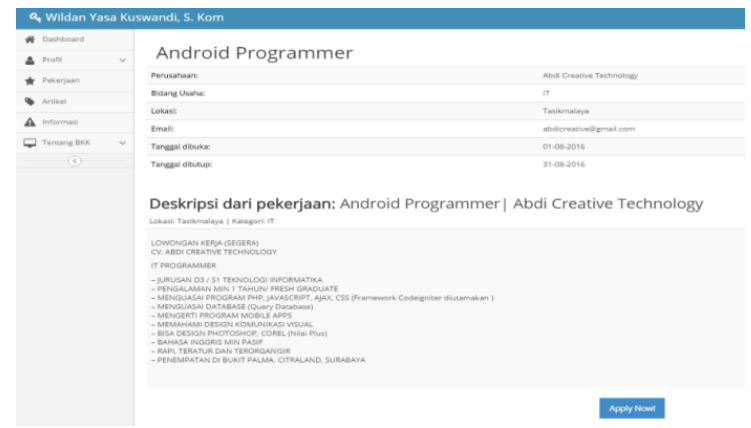

Gambar 10. Tampilan halaman detail pekerjaan 


\section{Pengujian}

Tabel 1. Proses Apply Pekerjaan

\begin{tabular}{|c|c|c|c|c|c|}
\hline No & $\begin{array}{l}\text { Sekenario } \\
\text { penguviain }\end{array}$ & Test case & $\begin{array}{l}\text { Hasili ang } \\
\text { diharapan }\end{array}$ & $\begin{array}{c}\text { Hasil } \\
\text { penguguan }\end{array}$ & Kesimpulan \\
\hline 1. & 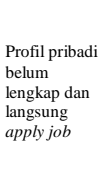 & 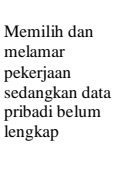 & 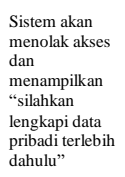 & $\begin{array}{c}\text { Sesuai } \\
\text { harapanan }\end{array}$ & Valid \\
\hline 2. & Apply job & $\begin{array}{l}\text { Memilih dan } \\
\text { melakuann } \\
\text { plemaran } \\
\text { pekerjaan } \\
\text { dengan } \\
\text { menckan } \\
\text { tombol "apply" }\end{array}$ & 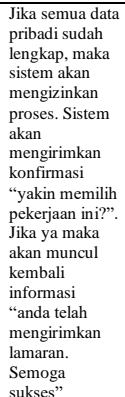 & $\begin{array}{c}\text { Sesuai } \\
\text { harapana }\end{array}$ & Valid \\
\hline
\end{tabular}

\section{KESIMPULAN DAN SARAN}

Pembahasan yang telah dipaparkan, tentunya proyek penelitian ini memiliki kelebihan dan kekurangan. Untuk kelebihannya adalah sebagai berikut:

a. Aplikasi ini merupakan aplikasi pencarian kerja online berbasis web yang dapat menyampaikan informasi lowongan pekerjaan secara realtime kepada siswa dan alumni melalui akun yang telah terdaftar.

b. Dengan adanya aplikasi ini pihak pelamar dapat langsung mengunggah berkas yang ditujukan kepada pihak perusahaan dan langsung sampai ke database perusahaan.

c. Dengan adanya aplikasi ini dapat menghubungkan antara pihak pencari kerja yaitu siswa/alumni dan perusahaan melalui lembaga resmi BKK. Aplikasi ini dapat mempermudah proses penyebaran dan pencarian lowongan pekerjaan.

d. BKK diuntungkan dengan mendapat laporan tentang progress siswa dan alumninya, sehingga dapat menjadi bahan evaluasi untuk meningkatkan kualitas BBK dan SMK Negeri 1 Kota Tasikmalaya.

Berikut kekurangannya: a. Terkadang masih adanya keterlambatan proses update pemberitahuan lowongan pekerjaan dikarenakan sistem masih dalam tahap pengembangan.

b. Masih ada beberapa fitur yang belum berfungsi maksimal.

c. Tidak adanya fasilitas untuk mengganti warna atau tampilan halaman website.

d. Belum tersedia fasilitas seperti SMS Gateway.

\section{DAFTAR PUSTAKA}

A.S Rosa dan M.Shalahuddin. 2014. Rekayasa Perangkat Lunak Struktur dan Berorientasi Objek. Bandung: Informatika.

Fadul, F. 2014, Agustus 23. Diambil dari: dul.web.id Referensi Web Design Indonesia:

http://dul.web.id/bootstrap/3/tutstips/belajar-bootstrap-untukpemula.php. (20 Mei 2015).

Fahmi, Khairul. Agus Tri Haryono, Indah Fitri Astuti dan Dedy Cahyadi. 2016. Perancangan Dan Implementasi Aplikasi Perpustakaan Berbasis Multitenant. Jurnal Informatika Mulawarman Vol. 11 No. 1 Februari 2016.

Haryani, Putu Yeni. 2013. Korelasi Antara Pengembangan Karir. Jurnal Buletin Studi Ekonomi, Vol. 18, No. 2, 2013: 183.

Hidayat, Akik dan Wizzy Mochammad Andhika. 2016. Sistem Informasi Penyewaan Lahan Dan Pelayanan Konstruksi Di Pasar Cimol Berbasis Web. Vol 3, No.2. 2016.

Nugroho, Yusuf Sulistiyo, and Abadi Nugroho. 2012. SISTEM INFORMASI LOWONGAN KERJA BERBASIS WEB DAN WAP. Prosiding Seminar Nasional Aplikasi Sains \& Teknologi (SNAST) Periode III, 2012: 380.

Riyanto, Slamet. 2014. Step by Step Adobe Photoshop to CSS3. Jakarta: Elex Media Komputindo. 
Sibero, Alexander F. K. Kitab Suci Web Programming. Yogyakarta: MediaKom, 2011.

Sibero, Alexander F.K . 2013. Web Programming Power Pack. Yogyakarta: Mediakom.

Sujatmiko Septiyan dan Dony Ariyus. 2018. Analisis Google Image Index Perbandingan Seo Expired Domain Dan Fresh Domain Studi Kasus Toko Online. ISSN : 2302-3805 Seminar Nasional Teknologi Informasi dan Multimedia. UNIVERSITAS

AMIKOM Yogyakarta.

Sutabri Tata. 2012. Analisis Sistem Informasi. Yogyakarta: CV Andi Offset.

Syahputra, Arman, and Kusuma Hati. 2015. PENGEMBANGAN SISTEM CAREER CENTER UNTUK DEPARTEMEN KONSELING. JURNAL KHATULISTIWA INFORMATIKA, VOL. 3, NO. 2, 2015: $133-134$

Tantra, Rudy. 2012. Manajemen Proyek Sistem Informasi. Yogyakarta : CV Andi Offset.

Wahana Komputer. 2012. Mudah \& Cepat Membuat Website Dengan CodeIgniter. Semarang: Penerbit ANDI.

Warman, Indra dan Atma Zahni. 2013. Rekayasa Web Untuk Pemesanan Handphone Berbasis Jquery Pada Permata Cell. Vol.15 No.2. Agustus 2013. Jurnal Momentum ISSN: 1693-752X 